\title{
Health Care System Transformation and Integration: A Call to Action for Public Health
}

Lindsay Wiley

wiley@wcl.american.edu

Follow this and additional works at: https://digitalcommons.wcl.american.edu/facsch_lawrev

Part of the Health Law and Policy Commons

\section{Recommended Citation}

Wiley, Lindsay, "Health Care System Transformation and Integration: A Call to Action for Public Health" (2017). Articles in Law Reviews \& Other Academic Journals. 1865.

https://digitalcommons.wcl.american.edu/facsch_lawrev/1865

This Article is brought to you for free and open access by the Scholarship \& Research at Digital Commons @ American University Washington College of Law. It has been accepted for inclusion in Articles in Law Reviews \& Other Academic Journals by an authorized administrator of Digital Commons @ American University Washington College of Law. For more information, please contact kclay@wcl.american.edu. 


\title{
Health Care System
}

Transformation and Integration: A Call to Action for Public Health

\author{
Lindsay F. Wiley and Gene W. Mattheres
}

\section{Introduction}

We are on the cusp of a total rewiring of the circuitry that connects public health departments, health care providers, third-party payers, and government programs. Experts have long argued for integration of public health and health care goals. ${ }^{1}$ Now, financial pressure to integrate is coming from both sides, creating unprecedented opportunities to serve public health goals by integrating them into financing and delivery structures within the better-resourced health care sector. But there are also challenges. The population perspective, social justice commitment, and structural interventions that characterize public health could easily be dismissed in favor of more individualistic strategies reliant on ineffective patient counseling and expensive technological solutions. In this unique moment, the health care sector is receptive to the public health perspective. Public health leaders must be ready to answer the call.

\section{The Drivers of Integration}

On the health care side, the Affordable Care Act (ACA) ${ }^{2}$ and the Medicare Access and Chip Reauthorization Act (MACRA) ${ }^{3}$ are accelerating a sweeping transformation of how health care is financed and delivered. In particular, new tax and reimbursement incentives are giving hospitals and other health care providers a financial stake in patient outcomes. These reforms enjoy bipartisan support and are likely to remain in place even if other provisions of the ACA are repealed.

Lindsay F. Wiley, J.D., M.P.H., is a Professor of Law at American University, Washington College of Law. Gene W. Matthews, J.D., is the Director of the Southeastern Regional Center of the Network for Public Health Law at the University of North Carolina Gillings School of Global Public Health.
New Internal Revenue Service (IRS) regulations ${ }^{4}$ strengthen and clarify the obligations of nonprofit hospitals, which make up more than half of all hospitals in the U.S., to invest in addressing their communities' health needs as a condition of their tax-exempt status. There are two distinct requirements. First, nonprofit hospitals must conduct community health needs assessments (CHNAs) every three years. ${ }^{5}$ Second, they must provide community benefits - programs and services to promote community health and access to health care - which they must report annually to the IRS using Form 990 Schedule H. ${ }^{6}$

Nonprofit hospitals report more than $\$ 62$ billion in annual community benefit spending. To date, however, the majority of community benefit spending is dedicated to downstream interventions: financial assistance to patients (charity care) and expenditures associated with Medicaid participation (for which reimbursements are often below cost). ${ }^{7}$ Community building activities - including physical improvements and housing, economic development, community support, environmental improvements, and leadership development and training for community members - are permitted, but the onus is on hospitals to justify the nexus between these activities and community health. ${ }^{8}$ In many instances, the mandated CHNA process identifies community building needs, but the IRS has not directly linked the two requirements by asking hospitals to indicate how much of their community benefit spending addresses needs identified through the CHNA.

In addition to new IRS requirements for nonprofit hospitals, virtually all providers are increasingly dependent on outcome-based payments. Because patient outcomes are heavily influenced by social-ecological factors (such as social connectedness, stable 
housing, and access to healthy food), tying payment to patient outcomes gives health care providers a greater stake in their communities. In response, hospitals and other providers are looking upstream within their patient catchment areas to anticipate and understand community needs and risks.

Supported by MACRA, the federal Department of Health and Human Services (HHS) has committed to transitioning half of all Medicare payments from fee-for-service to quality- or value-based models including bundled payments for episodes of care, shared savings for Accountable Care Organizations made up of hospitals and physician groups, and the Patient Centered Medical Home payment model for physicians - by the end of 2018. HHS aims to tie 90 percent of all remaining fee-for-service payments to outcome-based incentives (add-ons or deductions to all Medicare payments a provider receives), such as the Hospital Value Based Purchasing Program, the Hospital Readmissions Reduction Program, and (for physicians) the Merit-based Incentive Payment System. ${ }^{10}$ Similar approaches are being adopted by state Medicaid programs and private insurers.

On the public health side, local health departments are tackling increasingly complex threats with shrinking resources. While health spending is projected to grow at an average of 6 percent per annum over the next decade, the percentage allocated to public health is projected to decrease to 2.4 percent - down by a quarter from its peak in 2002. ${ }^{11}$ Not surprisingly, job loss at local health departments continues unabated. ${ }^{12}$

\section{Opportunities Generated by This Moment of Transformation}

There are many opportunities for health care sector incentives to move the needle on community health. Whether they do will depend on alignment with public health priorities and engagement of public health leaders.

Activities addressing the social determinants of health currently represent a small proportion of community benefit spending, but that could change. The IRS has existing authority to require nonprofit hospitals to link community benefit spending to the priorities they have identified through CHNAs. ${ }^{13}$ Local health departments could also encourage hospitals to commit more of their community benefit dollars to upstream activities. Fortunately, new resources are available to help stakeholders tackle the social determinants of health, including the CDC's Community Health Improvement Navigator, ${ }^{15}$ guides from the Catholic Health Association, ${ }^{16}$ and a new web resource under development that will provide easy access to the community benefit financial information that hospitals report to the IRS.

Health care providers' efforts to improve patient outcomes currently focus on individual behavior change, but they are beginning to take the next step toward community-level changes that facilitate healthy living. The patient-centered medical home, for example, is designed to coordinate care for chronic conditions and address barriers to patient adherence with providerrecommended lifestyle changes. In some cases, coordinators link patients to community resources such as subsidies for fresh produce and recreational facilities. These efforts could be boosted by linking them to community resource networks fostered by local health departments. ${ }^{14}$

New outcome-based alternative payment structures could also evolve in ways that are more attuned to public health goals. Some payments are already tied to outcomes with direct public health significance, such as the percentage of eligible patients who are offered a seasonal flu vaccination and rates of preventable hospital-acquired infections. ${ }^{17}$ More payments could be tied to outcomes with population-level significance in coming years, particularly with respect to chronic disease prevention.

Emerging initiatives illustrate the potential of integration. In North Carolina, for example, a large hospital system that is exempt from the IRS CHNA requirement decided on its own to undertake a community health improvement process. Public health experts assisted the hospital system - which serves patients in 10 different local jurisdictions across two states by mapping hot spots where social determinants put health at risk and helping hospital administrators reach out to local health directors. In Pennsylvania, the Governor's Office for Health Care Reform convened the major third-party payers operating in the state to adopt incentives for statewide implementation of the patient-centered medical home model for managing diabetes. New York City's Department of Health and Mental Hygiene uses its A1C Registry to aggregate data and connect patients and providers to community resources.

\section{Challenges Posed by the Integration of Public Health Goals into the Health Care Sector}

Fruitful integration of public health and health care goals depends on how public health leaders respond to several challenges.

After decades of health care industry dominance of the health policy agenda, the public health sector has come to undervalue itself. For several decades, highcost technological solutions and individualistic and 
ineffective patient counseling pushed public health law and policy into dormancy..$^{18}$ Local health departments became health care service providers of last resort. If those services are viewed as no longer needed in the wake of insurance coverage expansion, public health must make the case for its unique and vital role in health promotion and community development.

Providers and payers are on board with the prevention focus of public health, but they do not share its population perspective. ${ }^{19}$ Rather, they are steeped in the process of improving health one patient at a vidual to adopt healthier behaviors without changing the context to facilitate those behaviors, is largely ineffective compared to the structural, social-ecological approaches endorsed by most public health experts.

Although HHS and private insurers are moving toward outcome-based payment, older payment structures that reward technological solutions are still highly influential. Providers are conditioned to rely on the latest (often expensive) technology instead of working with patients and community members to achieve structural and social change to improve health. The

\section{Integration of population health goals into the organization of health} care delivery and financing cannot and should not be left to health care administrators alone. Social determinants of health, upstream prevention, and population health have only recently become watchwords in the health care sector; they have been the wheelhouse of public health experts for decades. Furthermore, local health departments have a powerful forum to connect with communities about the issues people care about. Few things are more politically potent than an enraged local health director with a good sound bite about how government failures are harming children and families.

time and controlling costs one insured individual at a time. When providers and payers talk about populations, they are talking about the patient populations assigned to them for a year. They have a lot of incentive to pick the cherries and drop the lemons. Public health authorities' obligation is to the public as a whole over the full life course; they do not get to choose whom to serve and whom to steer clear of. To the contrary, public health goals often require prioritizing the needs of people whose health, race, and socioeconomic status make them particularly vulnerable.

When providers and payers focus on prevention, they are still operating downstream ${ }^{20}-$ targeting individuals who are high risk because they have already developed markers of cardiovascular disease, for example. The whole notion of outcome-based payment puts a lot of faith in what providers can do to achieve good outcomes. This faith may be misplaced. Especially when it comes to non-communicable diseases associated with tobacco use, alcohol use, poor nutrition, and physical inactivity, providers rely heavily on individual patient education. Similarly, payers offer the individuals they insure financial incentives to attend behavior change programs instead of advocating for environmental changes to workplaces and communities. This approach, which puts the onus on the indi- predisposition of health care providers and payers is further fostered by deep cultural biases and the influence of industries harmful to the public's health, both of which favor individualistic, downstream, behavioral, and technological solutions to health risks.

\section{Conclusion: A Call for Public Health Leadership and Dialogue}

Health care providers and third-party payers have powerful incentives to reduce the costs of illness and injury; the question is how they will respond to those incentives. To date, the integration process has been driven primarily by the health care sector. What role should public health play? What strategies can public health leaders use to ensure that their unique perspective is heard by health care administrators? What skills do public health leaders require to engage in dialogue with the health care sector and how can public health education support those skills? Are there examples that can be drawn on to develop a set of best practices for engagement with the health care sector? What about the role of public health lawyers specifically? We raise these questions to start a dialogue within the public health community.

Integration of population health goals into the organization of health care delivery and financing cannot 
and should not be left to health care administrators alone. Social determinants of health, upstream prevention, and population health have only recently become watchwords in the health care sector; they have been the wheelhouse of public health experts for decades. Furthermore, local health departments have a powerful forum to connect with communities about the issues people care about. Few things are more politically potent than an enraged local health director with a good sound bite about how government failures are harming children and families.

Public health lawyers are well positioned to play a role in integration. They have the expertise to guide health departments and hospitals as they seek to understand and implement evolving tax policy and payment incentive requirements. Lawyers are trained in the painstakingly rigorous analysis of language. They can identify and clearly define how terms like "population health," "community health," "preventable," and "social determinants" are being used and modified as they are integrated into tax and payment structures. They can assist with the legal aspects of creating new backbone organizations to support stakeholder collaborations without running afoul of complex antitrust and fraud and abuse regulations. More broadly, they are well suited to assist with policy development. The marriage of evidence and political savvy in the context of mutual self-interest makes for a robust conversation that cannot happen unless public health leaders bring their A game.

\section{References}

1. Institute of Medicine, For the Public's Health: Investing in a Healthier Future (Washington, D.C.: The National Academies Press, 2012): at 15; Institute of Medicine, The Future of Public Health (Washington, D.C.: The National Academies Press, 1988): at 7-15.

2. Pub. L. No. 111-148.

3. Pub. L. No. 114-10.

4. Pub. L. No. 111-148 § 9007; 26 C.F.R. $\$ \$ 1.501(r)-1-7$.
5. 26 C.F.R. $\$ 1.501(\mathrm{r})-3$

6. 26 C.F.R. $\$ 1.501(\mathrm{r})-4$

7. S. Rosenbaum, "Hospitals as Community Hubs: Integrating Community Benefit Spending, Community Health Needs Assessment, and Community Health Improvement," March 9, 2016, available at <https://www.brookings.edu/research/ hospitals-as-community-hubs-integrating-community-benefitspending-community-health-needs-assessment-and-community-health-improvement/> (last visited January 25, 2017)

8. Internal Revenue Service, U.S. Department of the Treasury, Instructions for Schedule H (Form 990), available at <https:// www.irs.gov/pub/irs-pdf/i990sh.pdf> (last visited January 25, 2017).

9. The Network for Public Health, Review of North Carolina Hospitals' Community Health Needs Assessments and Implementation Strategies, September 23, 2014, available at <http:// www.networkforphl.org/_asset/r1gg6w/Network-NC-CHNAReport.pdf> (last visited January 25, 2017).

10. S. Burwell, "Setting Value Based Payment Goals - HHS Efforts to Improve U.S. Health Care," New England Journal of Medicine 372, no. 10 (2015): 897-899.

11. Trust for America's Health, Investing in America's Health: A State-by-State Look at Public Health Funding and Key Health Facts (2016).

12. Robert Wood Johnson Foundation, "Local Health Departments in 2013: Budget and Job Cuts; Social Media and QI Increases," available at <https:www.rwjg.org/en/culture-ofhealth/2014/02/local_health_departm.html> (last visited October 12, 2016).

13. See Rosenbaum, supra note 7 .

14. L. F. Wiley, "Diabetes as a Community-Managed Social Phenomenon: A Health Justice Case Study, Houston Journal of Health Law and Policy (forthcoming 2017).

15. Centers for Disease Control and Prevention, U.S. Department of Health and Human Services, "CDC Community Health Improvement Navigator," available at <http://www.cdc.gov/ chinav/> (last visited January 25, 2017).

16. Catholic Health Association of the United States, "Assessing and Addressing Community Health Needs," available at <https://www.chausa.org/communitybenefit/assessing-andaddressing-community-health-needs> (last visited January 25 , 2017).

17. 42 C.F.R. $\$ 412.172$.

18. W. M. Sage and K. McIlhatten, "Upstream Health Law," Journal of Law, Medicine E Ethics 42, no. 4 (2014): 535-549, at 535.

19. L. F. Wiley, "The Struggle for the Soul of Public Health," Journal of Health Policy, Politics, and Law (2016).

20. L. O. Gostin and L. F. Wiley, Public Health Law: Power, Duty, Restraint, 3rd ed. (Berkeley: University of California Press, 2016): at 16 . 